\title{
Long-term total solar radiation variability at the Polish Baltic coast in Kolobrzeg within the period 1964-2013
}

\author{
Małgorzata Kleniewska \\ Warsaw University of Life Sciences (SGGW), Division of Meteorology and Climatology, Nowoursynowska 166, 02-787 \\ Warsaw, Poland, e-mail: malgorzata_kleniewska@sggw.pl
}

\section{Bogdan H. Chojnicki}

Poznań University of Life Sciences, Meteorology Department, Piatkowska 94, 60-649 Poznań, Poland

\author{
Manuel Acosta \\ Global Change Research Institute, Department of Matters and Energy Fluxes, CAS, v.v.i., Belidla $4 a, 60300$ Brno, \\ The Czech Republic
}

\begin{abstract}
This study is based on a 50-year data series (1964-2013) of total solar radiation $(G)$ from the Kołobrzeg station that is located on the Polish Baltic Sea coast and is characterised by a very high level of air quality. To find and remove gross errors, quality control checking procedures were applied in this study. Additionally, the homogeneity of the $G$ series in this study has been tested on a monthly basis by using of the Standard Normal Homogeneity Test for single shifts.

We found a statistically non-significant decrease in $G$ during the period from 1964 to 2013. The decrease in the 5-year mean total solar radiation is evident from the beginning of the 1980s, with the minimum mean value occurring in the second half of the 1990 s, while $G$ slightly increased from the early 2000 s. The analysis of seasonal $G$ patterns shows that total solar radiation in summer is the most similar to the annual pattern and only the summer series trend shows a statistically significant decrease in $G$. We have also found two noticeable tendencies in monthly anomalies of $G$ over the studied decades; they are negative trends in May and August. The shape of the decadal daily $G$ histogram remained unchanged during the analysed decades.
\end{abstract}

Key words: total solar radiation, Kołobrzeg, dimming, brightening

Submitted 11 February 2016, revised 7 April 2016, accepted 9 August 2016

\section{Introduction}

The sum of the direct and diffuse radiation incident on the ground surface is variously called global solar radiation (Bogdańska, Podogrocki 2000; Podstawczyńska 2010), surface solar radiation (Sanchez-Lorenzo et al. 2013), total solar radiation (Matuszko 2014), surface insolation (Hinkelman et al. 2009) or solar/shortwave irradiance (Gilgen et al. 2009). The "solar radiation" nomenclature is discussed by Wild (2009) and Matuszko (2011 in Polish). In our study we will refer to it as total solar radiation $(G)$.

Variability in the amount of total solar radiation that reaches the Earth's surface is caused by external factors, such as changes in the Earth's orbital parameters (these cause changes over the geological time scale), solar activity (via changes of the solar constant), atmospheric water vapour, aerosols and cloudiness (these cause changes over shorter time periods) (Wild 2009).
A decline in total solar radiation ("dimming") has been observed during the period from the 1950s to the 1980s. Since the 1980s, stabilisation and increases ("brightening") in $G$ values have been detected in many places around the World, especially in industrialised regions (Sanchez-Lorenzo 2013). The causes of both the dimming and brightening phenomenon are very complex and studies conducted over the world show that fluctuations in total solar radiation are induced by changes in cloudiness (Russak 1990; Liepert 2002; Stjern et al. 2009; Chiacchio et al. 2010), cloud optical thickness (Liepert 1997, 2002) and atmosphere transparency (Uscka-Kowalkowska 2013). In addition, changes in aerosol emissions have also been identified as a cause of changes in the temporal dynamics of $G$ (Stanhill et al. 1992, 2001).

The aim of this study was to analyse the local total solar radiation variability at Kołobrzeg station, which is located on the Polish Baltic Sea coast and is characterised by a very high level of air quality. 


\section{Material and methods}

The basis of the research was a long-term data series of daily sums of total solar radiation $(G)$ from Kołobrzeg station, collected over the period from 1964 to 2013.

Kołobrzeg is a city of about 50000 inhabiants, situated in the Pomerania region, on the coast of the Baltic Sea, in a SPA area covered by legal regulations ensuring environmental protection. In the nearest vicinity there are no large facilities that cause air pollution, except for small and medium-sized local boiler plants and home furnaces that burn solid fuel (mainly coal-fired). Air quality in the area is relatively good (WIOŚ 2014), mainly thanks to its location away from large industrial centres and the strong mixing of air due to the vicinity of a large water body - the Baltic Sea. Sulphur dioxide and nitrogen dioxide are the main air pollutants in Pomerania and their concentration is smaller than in the interior and the south of Poland (Kicińska 2001a, b).

The analysis was conducted on daily total solar radiation data obtained from the World Radiation Data Centre WRDC. The daily sums of $G$ are expressed in $\mathrm{J} \mathrm{cm}^{-2}$. Monthly, seasonal and annual values of total solar radiation were calculated as the sums of diurnal values and expressed in $\mathrm{MJ} \mathrm{m}^{-2}$. The analysed WRDC data is a product of the actinometrical network of the Polish Institute of Meteorology and Water Management (IMGW). The initial data quality control is performed within the IMGW (Chwieduk, Bogdańska 2001) and the second step of this analysis is realised in the WRDC (https://www.wmo.int/ pages/prog/arep/gaw/solar-radiation.html). However, additional quality control checks have also been applied in this study. These checks were performed on a daily data set in order to find and remove gross errors (Aguilar et al. 2003). The homogeneity of the $G$ series in this study has been tested on a monthly basis by using the SNHT (Standard Normal Homogeneity Test) for single shifts (Alexandersson, Moberg 1997; Sanchez-Lorenzo 2013), and implemented using the AnClim software (Štěpănek 2008).

Total solar radiation at Kołobrzeg station is measured using the CM6B pyranometer by Kipp\&Zonen (http:// wrdc.mgo.rssi.ru/). More details about sensors used in the Polish actinometrical network is available in Bogdańska et al. (2002). For the analysis of $G$ values in seasons, a 13-year Gaussian low-pass filter was applied to indicate periodical trends (Sanchez-Lorenzo 2013).

\section{Results and discussion}

\subsection{Multiannual total solar radiation variability}

The annual sums of total solar radiation in Kołobrzeg during the period from 1964 to 2013 ranged from
$3481 \mathrm{MJ} \mathrm{m}^{-2}$ (1966) to $4190 \mathrm{MJm}^{-2}$ (1968) and the mean value for the whole analysed period was $3841 \mathrm{MJm}^{-2}$. The values obtained are higher than those reported by Bogdańska and Podogrocki (2000) for the period from 1961 to 1995 in Kołobrzeg, where minimum, maximum and mean values were $3428 \mathrm{MJm}^{-2}, 4138 \mathrm{MJm}^{-2}$ and $3829 \mathrm{MJ} \mathrm{m}^{-2}$, respectively.

Analysis of total solar radiation trends indicates a statistically non-significant decrease in Kołobrzeg $\left(-2.9 \mathrm{MJ} \mathrm{m}^{-2}\right.$ per year). The decrease in total solar radiation is evident from the beginning of the 1980s, with the minimum 5-year mean $G$ value (3731 $\mathrm{MJ} \mathrm{m}^{-2}$ ) occurring in the second half of the 1990s (Fig. 1). The biggest negative trend we have found was in the 1968-1987 period (20.6 $\mathrm{MJ} \mathrm{m}^{-2}$ per year) and it corresponds with results obtained for Kołobrzeg by Russak (1990). Total solar radiation studies conducted in Poland by other authors indicate varied trends. For example, an increase in total solar radiation in Wrocław within the years 1961-2012 (Bryś 2013) and a decrease in $G$ in Krakow during the period from 1884 to 2010 (Matuszko 2014). From the early 2000s, $G$ values in Kołobrzeg slightly increased.

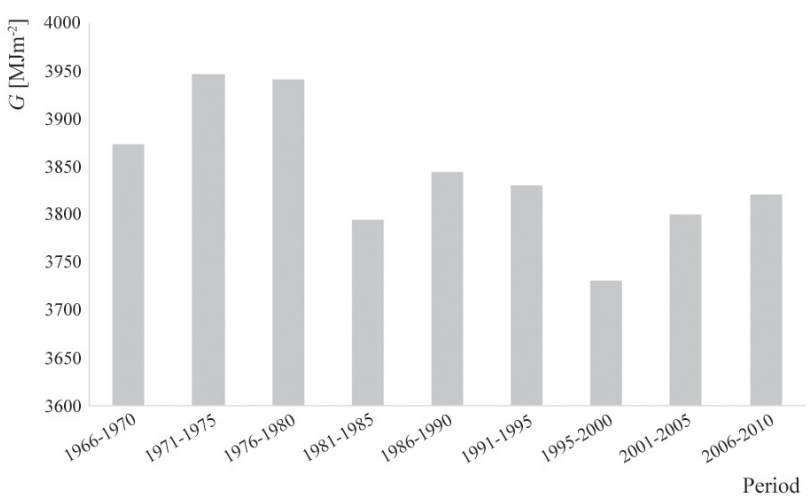

Fig. 1. The 5-year mean of total solar radiation sum $(G)$ at Kołobrzeg station within the period 1964-2013 [MJm-2]

The year-to-year annual sums of $G$ varied within the range of $10 \%$. The highest increase in annual $G$ values was recorded between 1967 and $1968\left(+432 \mathrm{MJm}^{-2}\right)$, while the largest decrease was found between 1982 and 1983 $\left(-391 \mathrm{MJ} \mathrm{m}^{-2}\right)$.

\subsection{Seasonal analysis}

The analysis of seasonal $G$ patterns (Fig. 2) shows that the dynamics of $G$ in summer is most similar to the annual pattern. The correlation coefficient between mean annual and seasonal series ranges between 0.05 in winter to 0.74 in summer.

Regarding linear trends for seasons, only the summer series shows a statistically significant decrease in $G$ dur- 

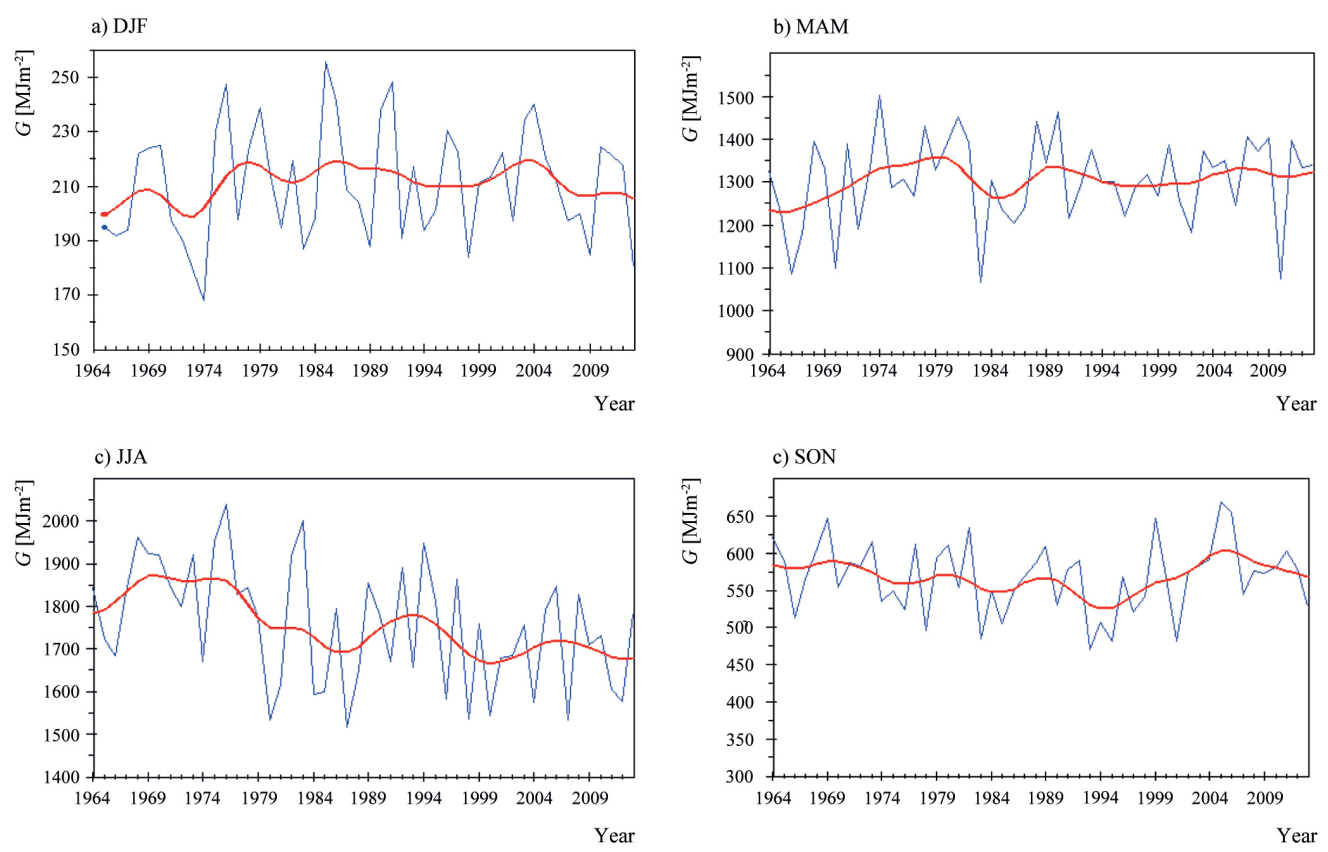

Fig. 2. Seasonal total solar radiation runs (blue line) filtered with 13-year Gaussian low-pass filter (red line) for the 1964-2013 period in Kołobrzeg

ing the 1964-2013 period (3.7 $\mathrm{MJ} \mathrm{m}^{-2}$ per year), while during the other seasons the rates of change were fairly small (max $0.8 \mathrm{MJm}^{-2}$ per year) and statistically non-significant.

\subsection{Annual course of total solar radiation}

The analysis of monthly values of total solar radiation is very useful for long-term studies of mass and energy exchange between ecosystems and the atmosphere (Baldocchi 2000). For this reason the next step of the study consisted of analysing the variation and trends in mean monthly $G$ values in the years from 1964 to 2013 (Fig. 3, Table 1).

The greatest mean monthly $G$ values during each year were found in June (19 cases), May (18 cases) and July (13 cases), while the highest mean monthly value in the whole period 1964-2013 was found in June $\left(628.0 \mathrm{MJ} \mathrm{m}^{-2}\right)$.

The $G$ values in June contributed the most to annual $G$ sums in the decades 1971-1980 (16.6\%) and 2001-2010 (16.5\%, Table 1). The two decades 1981-1990 and 19912000 were dimmed and the contribution of June $G$ values during these periods was reduced. This resulted in the

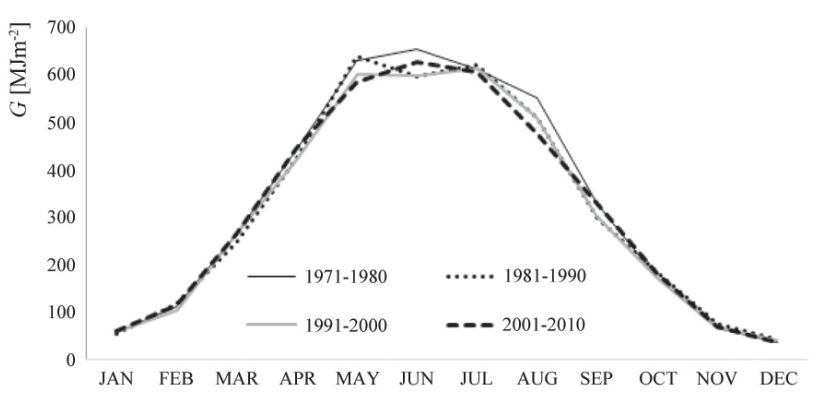

Fig. 3. The annual runs of $G$ in Kołobrzeg - binned in decades dominance of July and May $G$ values during these periods (Fig. 3, Table 1). The decrease in the contribution of August $G$ values to the annual sum is persistent during the whole study period.

The relatively high contribution of total solar radiation during May to the annual sums of $G$ can be explained by the frequent presence of Arctic air masses over Poland during this month, when the enhanced clearness of the air during these events causes an increase in the amount of direct solar radiation (the prevailing part of total solar radiation) that reaches the Earth's surface (Bryś 2013).

The large contribution of summer monthly values to the annual sums (Table 1) and their variability (Fig. 3) indicates that the warmer part of the year is crucial for annual $G$ values.

Emissions of air pollutants in Poland are higher during the cooler part of the year (Bokwa 2008; Kleniewska, Rozbicka 2008; Majewski et al. 2011; Rozbicka et al. 2014; Żyromski et al. 2014) mainly because of heating needs, however these loads have been reduced since 1990 (Smith et al. 2011) due to the conversion of industrial activity. The decadal anomalies in monthly $G$ value trends over the cooler months do not reflect this fact (Fig. 4) as relative changes in $G$ during the studied periods show the same range over the whole year (Fig. 5). There are only two noticeable tendencies in monthly $G$ over the studied decades. These are negative trends in May and August. The August depletion corresponds with the summer negative trend (Fig. 1c). The negative tendency in May appears to have less impact on the trend observed during the spring (Fig. 1b). Both negative trends correspond with the decreasing 
Table 1 . The mean monthly $G$ sums $\left[\mathrm{MJm}^{-2}\right]$ and its contribution in annual sums [in brackets, $\%$ ] in Kołobrzeg

\begin{tabular}{|c|c|c|c|c|c|}
\hline \multirow{2}{*}{ Month } & \multicolumn{5}{|c|}{ Period } \\
\cline { 2 - 6 } & $1971-1980$ & $1981-1990$ & $1991-2000$ & $2001-2010$ & $1964-2013$ \\
\hline January & $57.3(1.5)$ & $53.7(1.4)$ & $60.9(1.6)$ & $60.3(1.6)$ & $57.4(1.5)$ \\
\hline February & $113.7(2.9)$ & $117.6(3.1)$ & $106.5(2.8)$ & $114.6(3.0)$ & $113.8(3.0)$ \\
\hline March & $267.1(6.8)$ & $247.5(6.5)$ & $268.3(7.1)$ & $266.3(7.0)$ & $264.8(6.9)$ \\
\hline April & $444.3(11.3)$ & $426.8(11.2)$ & $424.2(11.2)$ & $446.1(11.7)$ & $429.4(11.2)$ \\
\hline May & $631.6(16.0)$ & $640.3(16.8)$ & $604.3(16.0)$ & $587.4(15.4)$ & $611.1(15.9)$ \\
\hline June & $654.8(16.6)$ & $597.6(15.6)$ & $599.4(15.9)$ & $627.9(16.5)$ & $628.5(16.4)$ \\
\hline July & $613.0(15.5)$ & $622.8(16.3)$ & $614.4(16.3)$ & $628.0(16.5)$ & $611.0(15.9)$ \\
\hline August & $553.5(14.0)$ & $512.2(13.4)$ & $512.8(13.6)$ & $478.9(12.6)$ & $516.5(13.4)$ \\
\hline September & $330.0(8.4)$ & $298.2(7.8)$ & $303.8(8.0)$ & $330.6(8.7)$ & $319.0(8.3)$ \\
\hline October & $173.8(4.4)$ & $184.1(4.8)$ & $174.9(4.6)$ & $182.4(4.8)$ & $178.9(4.7)$ \\
\hline November & $66.7(1.7)$ & $75.0(2.0)$ & $68.3(1.8)$ & $69.9(1.8)$ & $69.8(1.8)$ \\
\hline December & $37.6(1.0)$ & $43.6(1.1)$ & $42.9(1.1)$ & $38.1(1.0)$ & $40.3(1.0)$ \\
\hline
\end{tabular}

role of May and August in annual sums of $G$ (Table 1). The lack of clear tendencies in Kołobrzeg in the rest of the months suggests that the source of monthly $G$ variability was not related to the emission of air pollutants. Since Kołobrzeg station is located far away from significant sources of industrial pollution, it is a site that is ideal for studying the influence of other environmental factors on monthly variability in $G$. Factors which influence decreasing solar radiation, according to different authors, might be as follows: an increase in the amount of low clouds and atmospheric transparency coefficient decrease (Russak (1990) or changes in the cloud type (Liepert 1997).

\subsection{Daily sum of total solar radiation}

The daily amounts of total solar radiation vary strongly with time and this is mainly determined by meteorological conditions (Bogdańska, Podogrocki 2000). Daily $G$ values lower than $10 \mathrm{MJm}^{-2}$ were the most frequently observed values $(55.8 \%)$ and the contribution of this value class increased from $54.7 \%$ in the $1971-1980$ decade to $56.5 \%$ in the 1991-2000 decade. Simultaneously, the contribution

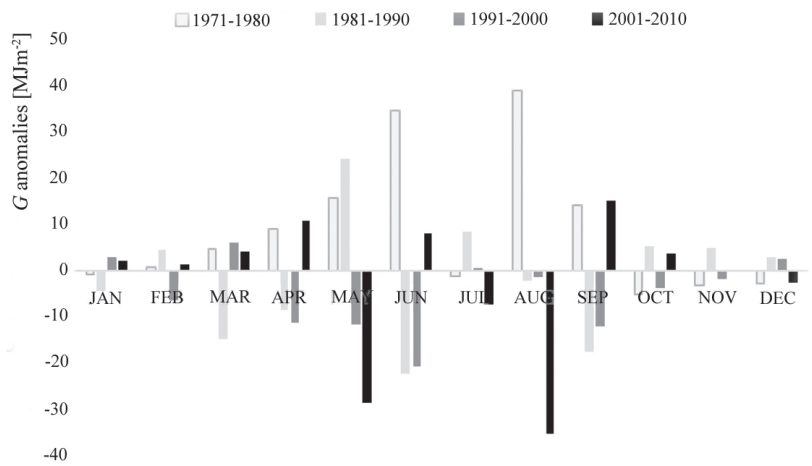

Fig. 4. Absolute monthly solar radiation anomalies from the 1971-2010 mean $\left[\mathrm{MJ} \mathrm{m}^{-2}\right]$ - binned in decades of $G$ values in the range $10.1-20.0 \mathrm{MJ} \mathrm{m}^{-2}$ increased from $25.3 \%$ to $26.9 \%$ (Fig. 6). The observed daily $G$ values higher than $30 \mathrm{MJ} \mathrm{m}^{-2}$ decreased from $1.9 \%$ (the 1970s) to $0.05 \%$ (the 2000s). The shape of the decadal daily $G$ histogram remained unchanged during the analysed decades. Such stability was not found in the Warsaw agglomeration (Kleniewska, Chojnicki 2016), where the distribution of daily sums of $G$ has changed since 1980, and the frequency of values above $20,0 \mathrm{MJ} \mathrm{m}^{-2}$ have increased and values below 5,0 $\mathrm{MJ} \mathrm{m}^{-2}$ have decreased.

\section{Concluding remarks}

A statistically non-significant decrease in $G\left(-2.9 \mathrm{MJ} \mathrm{m}^{-2}\right.$ per year) was found in Kołobrzeg for the period from 1964 to 2013. However, the largest, statistically significant, negative trend $\left(20.6 \mathrm{MJ} \mathrm{m}^{-2}\right.$ per year) was observed in the 1968 1987 period. A decrease in the 5-year total solar radiation from the beginning of the 1980s is evident. The minimum 5 -year total solar radiation value occurred in the second half of the 1990s (3731 $\left.\mathrm{MJm}^{-2}\right)$, while this value slightly increased from the early 2000 s.

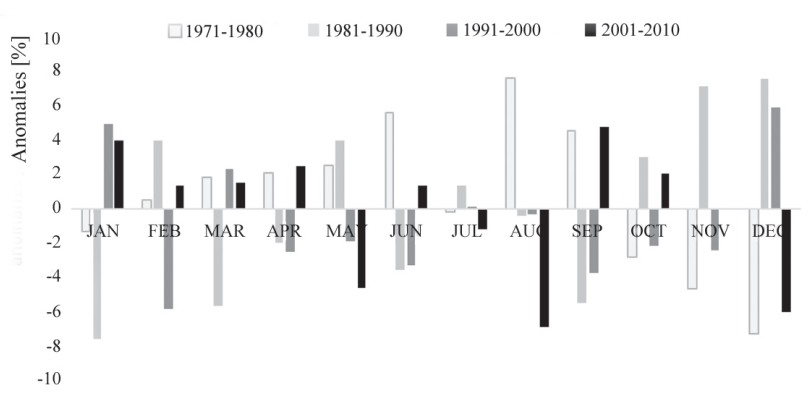

Fig. 5. Total monthly solar radiation relative anomalies from the 1971-2010 mean [ $\mathrm{MJ} \mathrm{m}^{-2}$ ] - binned in decades 


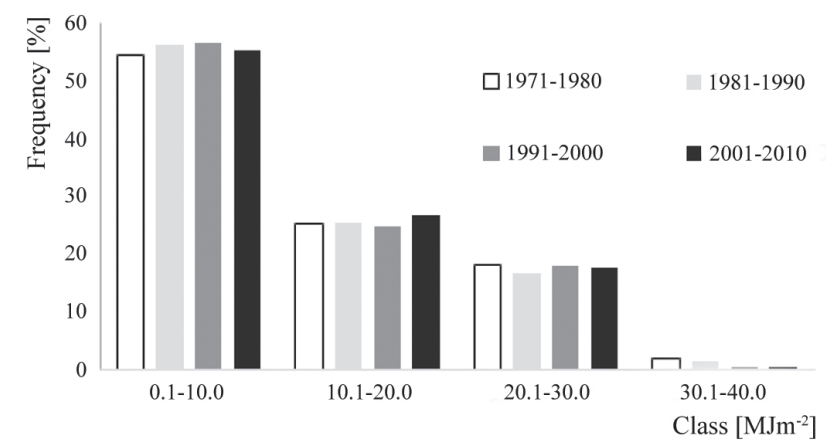

Fig. 6. The histogram of daily $G$ values $\left[\mathrm{MJm}^{-2}\right]$ for Kołobrzeg - binned in decades

The analysis of seasonal $G$ patterns showed that the dynamics of $G$ in summer is the most similar to the annual pattern $(R=0.74)$ and only the summer series trend shows a statistically significant decrease $\left(3.7 \mathrm{MJ}^{-2}\right.$ per year). This corresponds with the negative trend observed within the studied period. There are only two noticeable tendencies in monthly anomalies of $G$ over the studied decades and they are negative trends in May and August. The rest of the months in the analysed decades do not show clear tendencies.

The daily values of $G$ have not changed substantially during the analysed decades. The most frequently observed values of daily $G$ lower than $10 \mathrm{MJ} \mathrm{m}^{-2}$ increased between the 1970 s and 2000 s from $54.7 \%$ to $56.5 \%$, respectively. Simultaneously, the contribution of $G$ values higher than $30 \mathrm{MJ} \mathrm{m}^{-2}$ decreased between the 1970 s to the $2000 \mathrm{~s}$ from $1.9 \%$ to $0.05 \%$, respectively.

Analysis of the monthly and daily $G$ values during the studied decades show that the Kołobrzeg station is largely unaffected by the impact of industrial emissions and it is expected that the long-term trends observed at this station are the result of regional and/or global changes observed in the atmosphere.

\section{Acknowledgments}

Manuel Acosta was supported by the Ministry of Education, Youth and Sports of the Czech Republic within the National Sustainability Programme I (NPU I), grant number LO1415.

\section{Bibliography}

Aguilar E., Auer I., Brunet M., Peterson T.C., Wieringa J., 2003, Guidelines on climate metadata and homogenization, WMOTD 1186, World Meteorological Organisation, Geneva, 52 pp., https://www.wmo.int/datastat/documents/WCDMP-53_1.pdf (data access 18.08.2016)

Alexandersson H., Moberg A., 1997, Homogenization of Swedish temperature data, Part I: Homogenity test for linear trends,
International Journal of Climatology, 17 (1), 25-34, DOI: 10.1002/(SICI)1097-0088(199701)17:1<25::AID-JOC103 $>3.0 . \mathrm{CO} ; 2-\mathrm{J}$

Baldocchi D., Falge E., Wilson K., 2001, A spectral analysis of biosphere-atmosphere trace gas flux densities and meteorological variables across hour to multi-year time scales, Agriculture and Forest Meteorology, 107 (1), 1-27, DOI: 10.1016/ S0168-1923(00)00228-8

Bogdańska B., Podogrocki J., 2000, Variation in total solar radiation on Polish territory in the period 1961-1995, (in Polish), Materiały Badawcze IMGW. Seria: Meteorology, 30, 43 pp.

Bogdańska B., Podogrocki J., Żółtowska K., 2002, The network of solar radiation measurements in Poland and the actinometric database, (in Polish) [in:] Działalność naukowa prof. Władysława Gorczyńskiego i jej kontynuacja, G. Wójcik, K. Marciniak (eds.), Adam Mickiewicz University Press, Toruń, 55-70

Bokwa A., 2008, Environmental Impacts of Long-Term Air Pollution Changes in Kraków, Poland, Polish Journal of Environmental Studies, 17 (5), 673-686

Bryś K., 2013, Dynamics of net radiation balance of grass surface and bare soil, (in Polish), Wrocław University of Environmental and Life Science, Wrocław

Chiachiao M., Ewen T., Wild M., Arabini E., 2010, Influence of climate shifts on decadal variations of surface solar radiation in Alaska, Journal of Geophysical Research: Atmospheres, 115 (D10), DOI: 10.1029/2009JD012533.

Chwieduk D., Bogdańska B., 2004, Some recommendations for inclinations and orientations of building elements under solar radiation in Polish conditions, Renewable Energy Journal, 29 (9), 1569-1581, DOI: 10.1016/j.renene.2003.12.018

Gilgen H., Roesch A., Wild M., Ohmura A., 2009, Decadal changes in shortwave irradiance at the surface in the period from 1960 to 2000 estimated from Global Energy Balance Archive Data, Journal of Geophysical Research: Atmospheres, 114 (D10), 1-12, DOI: 10.1029/2008JD011383

Hinkelman L.M., Stackhouse P.W., Wielicki B.A., Zhang T., Wilson S.R., 2009, Surface insolation trends from satellite and ground measurements: Comparisons and challenges, Journal of Geophysical Research: Atmospheres, 114 (D10), DOI: 10.1029/2008JD011004

Kicińska B., 2001a, The effects of atmospheric circulation on the concentration of sulphur dioxide in Poland, (in Polish), Studies in Geography, 28, 223-233

Kicińska B., 2001b, The air pollutants sulphur dioxide and nitrogen dioxide, (in Polish), [in:] Atlas klimatycznego ryzyka uprawy roślin w Polsce, C. Koźmiński, B. Michalska, Z. Bochenek, Z. Rawa (eds.), Akademia Rolnicza, Szczecin

Kleniewska M., Rozbicka K., 2008, The relationship between sulfur dioxide and nitrogen dioxide concentrations and wind velocity in Warsaw agglomeration, (in Polish), [in:] Klimat 
i bioklimat miast, K. Kłysik, J. Wibig, K. Fortuniak (eds.), Wydawnictwo UŁ, Łódź, 431-443

Kleniewska M., Chojnicki B.H., 2016, Long-term total solar radiation variability in Warszawa within the period 1964-2013, Acta Geographica Lodziensia, 104, in press

Liepert B.G., 1997, Recent changes in solar radiation under cloudy conditions in Germany, International Journal of Climatology, 17 (14), 1581-1593, DOI: 10.1002/(SICI)10970088(19971130)17:14<1581::AID-JOC214>3.0.CO;2-H

Liepert B.G. 2002, Observed reductions of surface solar radiation at sites in the United States and worldwide from 19611990, Geophysical Research Letters, 29 (10), 1421

Majewski G., Kleniewska M., Brandyk A., 2011, Seasonal variation of particulate matter mass concentration and content of metals, Polish Journal of Environmental Studies, 20 (2), 417-427

Matuszko D., 2011, On the terminology of solar radiation, (in Polish), Polska Energetyka Słoneczna, 2-4, 27-30

Matuszko D., 2014, Long-term variability in solar radiation in Krakow based on measurements of sunshine duration, International Journal of Climatology, 34 (1), 228-234, DOI: $10.1002 /$ joc.3681

Podstawczyńska A., 2010, UV and global solar radiation in Łódź, Central Poland, International Journal of Climatology, 30 (1), 1-10, DOI: 10.1002/joc. 1864

Rozbicka K., Majewski G., Rozbicki T., 2014, Seasonal variation of air pollution in Warsaw conurbation, Meteorologische Zeitschrift, 23 (2), 175-179, DOI: 10.1127/09412948/2014/0453

Russak V., 1990, Trends of solar radiation cloudiness and atmospheric transparency during recent decades in Estonia, Tellus, 42 (2), 206-210, DOI: 10.1034/j.1600-0889.1990.t01-100006.x

Sanchez-Lorenzo A., Calbo J., Wild M., 2013, Global and diffuse solar radiation in Spain: Building a homogeneous dataset and assessing their trends, Global and Planetary Change, 100, 343-352, DOI: 10.1016/j.gloplacha.2012.11.010

Smith S.J., van Aardenne J., Klimont Z., Andres R.J., Volke A., Arias S.D., 2011, Antropogenic sulphur dioxide emissions: 1850-2005, Atmospheric Chemistry and Physics, 11, 11011116, DOI: 10.5194/acp-11-1101-2011
Stanhill G., Moreshet S., 1992, Global radiation climate changes: the world network, Climatic Change, 21 (1), 57-75, DOI: 10.1007/BF00143253

Stanhill G., Cohen S., 2001, Global dimming: a review of the evidence for a widespread and significant reduction in global radiation with discussion of its probable causes and possible agricultural consequences, Agricultural and Forest Meteorology, 107 (4), 255-278, DOI: 10.1016/S0168-1923(00)00241-0

Štěpánek P., 2008, AnClim - software for time series analysis, Dept. of Geography, Faculty of Natural Sciences, MU, Brno, http://www.climahom.eu/AnClim.html (data access 18.08.2016)

Stjern C.W., Kristjánsson J.E., Hansen A.W., 2009, Global dimming and global brightening - an analysis of Surface radiation and cloud cover data in northern Europe, International Journal of Climatology, 29 (5), 643-653, DOI: 10.1002/ joc. 1735

Uscka-Kowalkowska J., 2013, An atmospheric extinction of direct solar radiation on Mt. Kasprowy Wierch, Poland, Atmospheric Research, 134, 175-185, DOI: 10.1016/j.atmosres.2013.08.002

Wild M., 2009, Global dimming and brightening: a review, Journal of Geophysical Research: Atmospheres, 114 (D10), DOI: 10.1029/2008JD011470.

WIOŚ, 2014, Information on the state of the environment in Kołobrzeg County in the year 2013, (in Polish), Voivodship Inspectorate for Environmental Protection in Szczecin, 28 pp., http://www.wios.szczecin.pl/bip/files/ (data access 18.08.2019)

WIOŚ, 2015, Information on the state of the environment in Kołobrzeg County in the year 2014, (in Polish), Voivodship Inspectorate for Environmental Protection in Szczecin, 23 pp., http://www.wios.szczecin.pl/bip/files/ (data access 18.08.2019)

World Radiation Data Centre, http://wrdc.mgo.rssi.ru/ Żyromski A., Biniak-Pieróg M., Burszta-Adamiak E., Zamiar Z., 2014, Evaluation of relationship between air pollutant concentration and meteorological elements in winter months, Journal of Water and Land Development, 22 (1), 25-32, DOI: 10.2478/jwld-2014-0019 